\title{
UMRAH HEALTH SURVEILLANCE SYSTEM IN PORT HEALTH OFFICE CLASS I SURABAYA
}

\section{Sistem Surveilans Kesehatan Umrah di Kantor Kesehatan Pelabuhan Kelas I Surabaya}

\author{
Bangun Cahyo Utomo ${ }^{1}$, Chatarina Umbul Wahjuni², Windhu Purnomo ${ }^{3}$ \\ ${ }^{1}$ Port Health Office Class 1 Surabaya, bangun.md1@gmail.com \\ ${ }^{2}$ Department of Epidemiology, Public Health Faculty, Universitas Airlangga, chatrin03@yahoo.com \\ ${ }^{3}$ Department of Biostatistics and Demography, Faculty of Public Health, Universitas Airlangga, \\ bangun.md1@gmail.com \\ Corresponding Author: Bangun Cahyo Utomo, bangun.md1@gmail.com, Port Health Office Class 1 \\ Surabaya, East Perak St No.514-516, North Perak, Pabean Cantian, Surabaya City, East Java, Indonesia, \\ Postal Code 60165
}

\section{ARTICLE INFO \\ Article History: \\ Received June, $19^{\text {th }}, 2019$ \\ Revised form July, $19^{\text {th }}, 2019$ \\ Accepted August, $29^{\text {th }}, 2019$ \\ Published online August, $30^{\text {th }}, 2019$}

\author{
Keywords: \\ surveillance system; \\ health; \\ umroh pilgrims; \\ port health office class 1 surabaya
}

\section{Kata Kunci:}

sistem surveilans;

kesehatan;

jemaah umrah;

kantor kesehatan pelabuhan kelas 1 surabaya

\begin{abstract}
Background: The number of Umrah pilgrims is three times higher than hajj pilgrims. The Hajj pilgrims' welfare can be monitored through an established surveillance system, while Umrah pilgrims' welfare hasn't had a surveillance system. Purpose: This study aims to develop an Umrah pilgrims' health surveillance system in the Port Health Office (PHO)Class I of Surabaya. Method: This research was a descriptive study conducted at Port Health Office Class I of Surabaya in February-August 2018. The data was collected by indepth interviews. The informants were the officers of Surabaya Port Health Office Class I, the Hajj Guidance Group (KBIH), and the operational manager of Umrah airline. The research variables were data collection, analysis, reports, reports of extraordinary conditions, dissemination, and utilization of results at the Port Health Office (PHO) Class I of Surabaya Results: The general objective of Umrah pilgrims' health surveillance system is the availability of epidemiological information on Umrah pilgrims'. The data collection was conducted actively and passively on the departure, in Saudi Arabia, and on arrival. The data analysis and interpretation aim to determine the frequency, distribution or proportion of Umrah pilgrims based on demographics, disease history, vaccination status and suspected findings. The information obtained was disseminated to the internal party of PHO Class I of Surabaya, stakeholders across sectors or programs and communities. System evaluation uses the attribute approach and takes place once a year. Conclusion: The system is developed based on the components of data collection, data processing, data analysis and interpretation, and dissemination.
\end{abstract}

C2019 Jurnal Berkala Epidemiologi. Published by Universitas Airlangga. This is an open access article under CC-BY-SA license (https://creativecommons.org/licenses/by-sa/4.0/)

\section{ABSTRAK}

Latar Belakang: Jumlah jemaah umrah tiga kali lipat lebih banyak dibanding jemaah haji. Kesehatan jemaah haji sudah memiliki sistem surveilans yang mapan, sedangkan kesehatan jemaah umrah belum 


\begin{abstract}
memiliki sistem surveilans. Tujuan: Penelitian ini bertujuan menyusun sistem surveilans kesehatan jemaah umrah di KKP Kelas I Surabaya. Metode: Penelitian ini merupakan penelitian deskriptif yang dilakukan di Kantor Kesehatan Pelabuhan Kelas I Surabaya pada Februari-Agustus 2018. Pengumpulan data dilakukan dengan wawancara mendalam kepada informan berdasarkan panduan wawancara mendalam. Informan dalam penelitian ini adalah petugas Kantor Kesehatan Pelabuhan Kelas I Surabaya, Kelompok Bimbingan Ibadah Haji (KBIH), dan manager operasional maskapai penerbangan umrah. Variabel penelitan ini adalah pengumpulan data, analisis, laporan, laporan kejadian luar biasa, penyebarluasan dan pemanfaatan hasil di Kantor Kesehatan Pelabuhan (KKP) Kelas I Surabaya. Hasil: Penyusunan sistem surveilans kesehatan jemaah umrah bertujuan untuk menyediakan informasi epidemiologi kesehatan jemaah umrah. Pengumpulan data dilakukan secara aktif dan pasif pada saat keberangkatan, saat di Arab Saudi, dan saat kedatangan dari Arab Saudi. Analisis dan interpretasi data bertujuan mengetahui frekuensi, distribusi atau proporsi jemaah umrah berdasarkan demografi, riwayat penyakit, status vaksinasi dan penemuan suspek. Informasi yang dihasilkan didiseminasikan ke internal KKP Kelas I Surabaya, lintas sektor atau lintas program dan masyarakat. Evaluasi sistem menggunakan pendekatan atribut, dilakukan satu tahun sekali. Kesimpulan: Sistem yang disusun berdasarkan komponen pengumpulan data, pengolahan data, analisis dan interpretasi data, diseminasi.
\end{abstract}

C2019 Jurnal Berkala Epidemiologi. Penerbit Universitas Airlangga. Jurnal ini dapat diakses secara terbuka dan memiliki lisensi CC-BY-SA (https://creativecommons.org/licenses/by-sa/4.0/)

\section{INTRODUCTION}

Various causes can lead to health problems, in which they cannot only be solved from the health sector operationally but also require integrated and comprehensive management with the cooperation among sectors and programs as well. What needs to be undertaken is to develop a health epidemiological surveillance subsystem. One of which is the Epidemiological Surveillance of Matra Health (Ministry of Health RI, 2014).

Epidemiological surveillance of matra health is an ongoing and systematic analysis of health problems and risk factors to support matra health program by the government. Activities such as systematic and continuous observations are undertaken in a pilgrimage season,, including the data collection on events related to the health status of the pilgrims both when in Indonesia and in Saudi Arabia. the data collection was then completed by data processing, interpretation, and dissemination of the result analysis on time to stakeholders for prevention and control purposes (Ministry of Health RI, 2016).
Based on the data from Surabaya hajj embarkation, the number of high-risk pilgrims reach approximately $39 \%-62.07 \%$ over the past nine years. In 2017, there were 22,901 pilgrims with high risks $(62.07 \%)$. The top ten types of high risk are old age, hypertension, lipoprotein disorder and hyperlipidemia, non-insulin-dependent diabetes mellitus (NIDDM), cardiomegaly, obesity, disorders of purine, hypertensive heart disease, insulin-dependent diabetes mellitus, and gastritis. Based on the report of Meningitis Meningococcus vaccination service at Surabaya Port Health Office Class I, there is a significant increase in high-risk pilgrims every year. Yezli, Assiri, Alhakeem, Turkistani, \& Alotaibi (2016) stated that some of the main health problems related to the intensity of Hajj and Umrah pilgrims are respiratory problems and meningitis infections that are easily transmitted through droplets. According to Alqahtani et al (2016) health problems that occur in the hajj and umrah pilgrims are respiratory disorders that affect pilgrims returning to Bangladesh from the Middle East. They mainly caused by influenza.

Due to a large number of high-risk pilgrims to the pilgrimage, it is possible for the Umrah pilgrims 
also consist of high-risk pilgrims since they have similar characteristics. It could even be a higher risk for the Umrah pilgrims since there are no rules about health criteria for Umrah pilgrims. Based on the explanation above, it is necessary to strengthen the surveillance system to increase awareness of emerging and re-emerging diseases (Almutairi, Alsalem, Hassanain, \& Hotez, 2018). This study aims to develop a health surveillance system for Umrah pilgrims in PHO Class I of Surabaya to acquire data and information regularly, continuously, and validly as a part of the decisionmaking process in planning, implementing, monitoring, and evaluating health programs. It also helps to increase awareness and accelerates a precise response to outbreaks.

\section{METHODS}

This research was a descriptive study conducted at Port Health Office Class I of Surabaya in February-August 2018. The data was collected by in-depth interviews based on in-depth interview guidelines. The informants were the officers of Surabaya Port Health Office Class I, the Hajj Guidance Group (KBIH), and the operational manager of Umrah airline.

The concept of the surveillance system was adapted from the law of Indonesian ministry of health no. 45 of 2014 that the implementation of health surveillance is carried out through data collection, data processing, data analysis, and dissemination as an inseparable unit to produce objective, measurable information that can be compared across time, between regions, and between community groups. as material for decision making (Ministry of Health RI, 2014).

The research variables were data collection, analysis, reports, reports of extraordinary conditions, dissemination, and utilization of results at the Port Health Office (PHO) Class I of Surabaya. The data collection component was classified according to the time of implementation (on the departure, when in Saudi Arabia, and on arrival). It consists of data collection methods, types of data, data collection officers, data sources, facilities, and data collection tools. The process component consists of compiling a database structure and storing data. Output component acquired in the form of information. This research has passed the ethical test by Health Research Ethics Commission of Public Health faculty, Universitas Airlangga Number 58/EA/KEPK/2019.

\section{RESULTS}

The general purpose of the health epidemiological surveillance for Umrah pilgrimage is to provide epidemiological information of the Umrah pilgrimage health for detecting and responding to risk factors related to a disease, outbreaks, or epidemics. In addition, the specific purpose of this surveillance is to implement early vigilance due to the possibility of outbreaks or epidemics and their impact. The information availability was provided in the forms of frequency and proportion of Umrah pilgrims based on demographics, health status, ICV, morbidity, mortality, the implementation of investigation, and prevention of outbreaks.

\section{Scope}

The scope of health surveillance among pilgrims lies within the potential infectious disease surveillance that becomes Public Health Emergencies of International Concern (PHEIC) along with its risk factor. The potential infectious diseases included meningitis meningococcus, Ebola, and Middle East Respiratory Syndrome Corona Virus (MERS-CoV) considering these diseases remain to occur in Saudi Arabia. The risk factors mentioned above are the pilgrims health condition, meningitis meningococcus vaccination, contact with other pilgrims from infected countries and infectious animals, and visiting infected places or countries.

\section{Case Definition}

The case referred to Umrah pilgrimage health system is all risk disease factors that can cause an outbreak: MERS-CoV, meningitis meningococcus, and Ebola. A person is categorized as suspected MERS-CoV if he/she has two conditions. First, if the person suffers from Acute Respiratory Infections (ARIs) accompanied by three symptoms: fever $\geq 38^{\circ} \mathrm{C}$, cough, and pneumonia. Second, if a person has one of these four criteria: having a history of travel to Middle East (infected country) within 14 days before illness, found etiologic or other disease causes, the presence of health workers who ill with the same symptoms after treating Severe Acute Respiratory Infection (SARI) patients (especially patients who need intensive care). These criteria are remain taken into account regardless of residence or travel history unless an etiology/cause of other diseases were found. In addition, a person can be categorized as suspected MERS $\mathrm{CoV}$ if he/she suffers from Acute Respiratory Infection (ARIs) and has a history of close contact with 
confirmed cases or probable cases of MERS-CoV infection within 14 days before illness.

A person is diagnosed as meningococcal meningitis infected, if he/she has clinical symptoms such as sudden fever, severe headache, frequently accompanied by vomiting, stiff neck, and petechiae rashes with pink macules yet rarely emerge as vesicles. Furthermore, a person is diagnosed as Ebola virus-infected if he/she has typical symptoms, such as fever (> $\left.38^{\circ} \mathrm{C}\right)$, headache, muscle aches, joint pain, weakness, diarrhea (bleeding/not bleeding), vomiting, no appetite/loss of appetite, and abdominal pain. Other symptoms which sometimes emerge include red spots, red eyes, hiccups, coughing, sore throat, breathing problem, chest pain, painful swallowing, and external.

\section{Data Collection}

\section{On Departure}

Data collection on the departure of pilgrimage involved officers of Port Health office, i.e., doctors, nurses, epidemiologists or other health workers. The instruments used were the Umrah departure form and health certificate. At this stage of data collection, facilities and infrastructure used are forms, Office Stationery, UV scanners, computers, internet networks, and Health Quarantine System application.

At this stage, the data were collected actively and passively. There were three methods used in collecting data on the departure of pilgrimage. First, conducting interview to Hajj Guidance Group officers and checking the forms. Second, ICV observation, and third, flight departure reports (passive method).

The first method of data collection included Umrah pilgrims' individual characteristics: name, sex, age, address, ID card number, and passport number. Also, it collected data of health history in last month, vaccination for Umrah pilgrims (type, date, and vaccination places), and travel history,, including departure and arrival dates and aircraft's identity (aircraft name, flight number, registration number, flight departure and arrival date). The procedure was carried out by filling out the Umrah departure form, then submitted to the Port Health Office maximum four hours before the departure of Umrah pilgrims.

The data collected in the second method included proof of validity related to vaccination or International Certificate of Vaccination (ICV). The procedure was collecting Umrah pilgrims' ICV to the Port Health officer. Then, it was validated by checking the watermark using a UV scanner. If it was found doubt, it can be checked into the Health Quarantine System application. If it was valid, then the Umrah pilgrims can pass to the next phase. While, if it was invalid, Umrah pilgrims must be vaccinated and their departure must be delayed at least 10 days.

The data collected in the latter method consisted of the number of seats on the plane's travel route (the country/city visited), the health conditions when checked-in to the aircraft, and the use of assistive devices (wheelchairs/sticks) by pilgrims. The procedure to obtain the data started by completing T1 Departure Reporting Form by the Port Health officer when supervising the Umrah departure.

Information obtained on Umrah pilgrims' departure was the frequency and proportion of Umrah pilgrims based on sex and age, high- risk based on disease history, distribution of pilgrims per district/city, and the frequency of Umrah pilgrims without ICV legalization.

\section{When in Saudi Arabia}

In this stage, the data collection started when Hajj Guidance Group officers undertook data collection in Saudi Arabia actively. The data were gained from the Arab Hospital and tour travel. Also, Port Health officers, including doctors, nurses, epidemiologists or other health workers undertook the data collection.

Three data collected on the active method. First, the data of Umrah pilgrims' sickness, such as identity, diagnosis, date of illness, and place of care. Second, the data of deceased Umrah pilgrims, such as date of death, place of death, cause and chronology of death, mortification, and place of burial, and third, data of the outbreaks in Saudi Arabia/aircraft, such as the type and location of the outbreak, the etiology of the disease, as well as the countermeasures. The data collection conducted by Hajj Guidance Group by collecting data while in Arabic and submitting the data to Port Health Office.

\section{On Arrival}

Data collection on arrival was undertaken actively and passively. Active data collection was done by observation, physical examination, and interview. The data were collected from airlines, Hajj Guidance Group, and Port Health Office. Officers of Port Health Office i.e. doctors, nurses, epidemiologists or other health workers collected the data in this stage. Data collection instruments used were HPAGD, temperature recording form, 
T1 departure report, and epidemiological investigation. The facilities and infrastructure used were thermal scanner, mobile thermometer, emergency kit, Personnel Protective Equipment (PPE), Ambulance, office stationery, and early disease detection devices.

The data collected using the passive method included the health condition on the way home. The data collection procedure started from the airline reporting the arrival of the aircraft and the health conditions of the Umrah pilgrims on the plane to the Port Health Office maximum half an hour before the plane landed. The information obtained was the frequency and proportion of pilgrims who were sick in flight.

There were four types of data collected by employing the active method. First, the health condition at the airport when arrived (including temperature screening), second, data of deceased Umrah pilgrims at the airport (date, place, cause, and chronology of death, mortification, and place of burial), third, data of Umrah pilgrims (pilgrim identity, diagnosis, date of illness, and place of care), and fourth, outbreak data at the airport (type and place of outbreak, etiology of disease, and prevention efforts).

Procedure to collect the data of the health conditions started when Umrah pilgrims walked on a predetermined path through the thermal scanner. If there was a person with a temperature $\geq 38^{\circ} \mathrm{C}$, a further health check was conducted by the doctor at the health post of Post Health Office. If a person fits into suspicion criteria, he/she would be referred to Dr. Soetomo Hospital. The information obtained was the frequency and proportion of pilgrims in flight, the frequency of screening for body temperature $>38^{\circ} \mathrm{C}$, the frequency of pilgrims with PHEIC, and the frequency of pilgrims' debarkation referred to the hospital.

To collect the data of deceased Umrah pilgrims, the officers of Port Health Office checked and diagnosed the cause of death. The body was referred to the hospital to obtain a death certificate. The method of referral depends on the cause of death. If it is caused by a disease other than potential contagious infectious diseases, then the referral would be done in the normal way. Information obtained were the frequency and proportion of pilgrims passed away in flight.

Data collection for the sick Umrah pilgrims was gained when Hajj Guidance Group officers collected data while in Saudi Arabia and submitted them to the Port Health Office. The data were recorded by the officers of Post Health Office in a T1 return form. Information obtained were the frequency and proportion of pilgrims' polyclinic visitation when in Saudi Arabia and the frequency and proportion of pilgrims passed away.

To collect the data of outbreaks procedures at the airport, officers of Port Health Office verified the information and conducted an epidemiological investigation and countermeasures needed. The information obtained was the frequency and proportion of pilgrims with the suspected disease causing an outbreak, as well as the result of epidemiological investigations and outbreaks prevention efforts.

\section{Data Processing, Analysis and Interpretation}

On data processing, the researchers employed Microsoft Excel software since the data processed were simple variables and analysis. The data were presented in the forms of narrations, tables and graphics. The main purpose of Umrah health surveillance activities was to determine trends of health problems or risk factors. Analysis can be undertaken descriptively considering the needs of result analysis in the forms of frequency and proportion distributions. The interpretation was acquired by comparing the analysis result with the previous conditions or risk factors. The analysis can also be undertaken to assess the correlation between risk factors and health problems (Table 2).

\section{Dissemination}

The information obtained can be disseminated to several parties internally and externally in the Port Health Office of Class I of Surabaya. Internal dissemination usually defines as a report. There are four types of information that are disseminated to several parties: monthly report, annual report, incidental report, and bulletin.

The procedure for implementing monthly reports was that the program holder would disseminate this report to the direct supervisor/ echelon 4 at the maximum on the fifth day of the following month. Then, echelon 4 would disseminate to echelon 3 at the maximum on the seventh day of the following month. The next step is that the echelon 3 would disseminate to the head of the office at the maximum of the ninth of the following month. The program holder submits the reports or dissemination to the head of the office by email or hardcopy (printed). The head of the office would disseminate a maximum of the following 10 months to three parties, such as Airport Authority by email or hardcopy (printed), District/City Health Office, Provincial Health Office, and Directorate General of Diseases Prevention and Control by email, and the public by web. 
Table 2

Information and Method of Calculation

Frequency \& Proportion of Umrah pilgrims based on sex and age

The proportion of male Umrah pilgrims

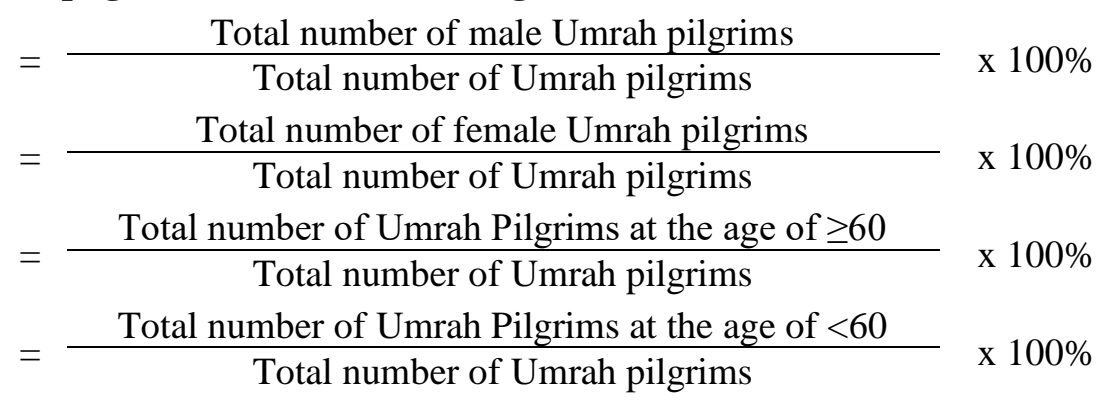

The proportion of female

Umrah pilgrims

The proportion of Umrah

Pilgrims at the age of $\geq 60$

The proportion of Umrah

Pilgrims at the age $<60$

Frequency \& proportion of high-risk Umrah pilgrims based on their medical history

Proportion of high-risk Umrah

pilgrims based on their medical

Total number of high-risk Umrah pilgrims based on

$=$ their medical history x $100 \%$

history

Total number of Umrah pilgrim

Frequency \& Proportion of Umrah pilgrims without ICV legalization

The proportion of Umrah

pilgrims without ICV

legalization

$=\quad$ Total number of Umrah pilgrims without ICV legalization

x $100 \%$

Frequency \& Proportion of Sick Umrah pilgrims in Saudi Arabia

$\begin{aligned} & \text { The proportion of Sick Umrah } \\ & \text { pilgrims in Saudi Arabia }\end{aligned}=\frac{\text { Total number of sick Umrah pilgrims in Saudi Arabia }}{\text { Total number of Umrah pilgrims }} \times 100 \%$

Pilgrims

The proportion of Deceased

Umrah Pilgrims

$$
=\frac{\text { Total number of deceased Umrah pilgrims }}{\text { Total number of Umrah pilgrims }} \times 100 \%
$$

Frequency \& proportion of screening for body temperature of $\geq 38^{\circ} \mathrm{C}$

Proportion of screening for

body temperature of $\geq 38^{\circ} \mathrm{C}$

Total number of screening for body temperature of

$=\frac{\geq 38^{\circ} \mathrm{C}}{\text { Total number of Umrah pilgrims }} \times 100 \%$

Frequency \& proportion of pilgrims suspected of PHEIC disease

proportion of pilgrims

suspected of PHEIC disease
Total number of proportion of pilgrims suspected of

$$
=
$$

\section{Total number of Umrah pilgrims}

Frequency \& proportion of debarkation congregants referred to hospital

proportion of debarkation

Total number of proportions of debarkation pilgrims

congregants referred to hospital = referred to hospital

Total number of Umrah pilgrims

\section{Frequency \& Proportion of Umrah pilgrims sick in flight}

The proportion of Umrah

pilgrims sick in flight

$$
=\frac{\text { Total number of Umrah pilgrims sick in flight }}{\text { Total number of Umrah pilgrims }}
$$

Frequency \& Proportion of Umrah pilgrims die on the flight

The proportion of Umrah pilgrims died on the flight

$$
=\frac{\text { Total number of Umrah pilgrims die on the flight }}{\text { Total number of Umrah pilgrims }} \times 100 \%
$$

Frequency \& Proportion of Umrah pilgrims with the suspected disease that can cause epidemics

The proportion of Umrah pilgrims with the suspected disease that can cause epidemics
Total number of Umrah pilgrims with the suspected

$$
=\frac{\text { disease that can cause epidemics }}{\text { Total number of Umrah pilgrims }} \times 100 \%
$$

The procedure for implementing incidental report dissemination included the program holder disseminating this report to the immediate supervisor/echelon 4 at the beginning of handling 
the incident. Then, echelon 4 would disseminate to the echelon 3. The next step is that the echelon 3 would disseminate to the head office. How to submit reports or dissemination from program holders to the head of the office was taken place through WhatsApp Group. The head of the office would conduct dissemination to Airport Authority, PAP, District/City Health Office, Provincial Health Office, and PHEOC Ministry of Health via email.

The procedure for the implementation of the dissemination of the bulletin is that the program holder disseminates directly to the supervisor, external parties, and the community every 6 months (July and January) by printing and distributed to the work areas and the community.

\section{Evaluation of Surveillance System}

The evaluations were carried out using the attribute approach, including simplicity, flexibility, acceptability, sensitivity, positive predictive value, representativeness, timeliness, data quality, and stability. Evaluation of the surveillance system as a whole is carried out once a year by the Head of the Quarantine Control and Epidemiological Surveillance Division at Port Health Office Class I of Surabaya. The informant is the Umrah pilgrims' health surveillance officer. The method used is indepth interviews (in-depth interview). The instrument used was an in-depth interview guide.

\section{DISCUSSION}

The purpose of the Umrah health surveillance system was early awareness of the disease. MERS $\mathrm{CoV}$ KLB, i.e., early detection is done through an increase in indicator-based surveillance activities or routine and event-based surveillance (event-based surveillance) that is actively carried out (Memish et al., 2014). The activity was carried out to find suspected cases of MERS-CoV suspected requiring follow-up epidemiological investigations, including taking clinical specimens to obtain laboratory confirmation and case management (Wignjadiputro et al., 2018).

The scope specified in the Umrah pilgrim's health surveillance system is a potentially infectious disease that is PHEIC namely meningococcal meningitis, Ebola, and MERS CoV with consideration of the occurrence of cases of this disease in Saudi Arabia and risk factors for transmission from other countries. This is because Saudi Arabia is a gathering place for Umrah pilgrims from all countries that can transmit various diseases (Zumla et al., 2016). This is supported by several reports of diseases in Saudi Arabia. One of them is the MERS CoV disease which was first discovered in Saudi Arabia (WHO, 2015). In Indonesia, until 2017, There had not been any case found to be stated as positive. However, it needs to be considered because the mobility of the Indonesian population from and to Saudi Arabia remains high. The mobility to and from the infected countries is a risk factor for the spread of disease in Indonesia, including pilgrims or Umrah who are in contact with citizens of affected countries (Gardner, Chughtai, \& Maclntyre, 2016). MERS-CoV affected countries are Saudi Arabia, Jordan, Qatar, United Arab Emirates, United Kingdom, Germany, France, Italy and Tunisia. WHO stated that the transmission from human to human is still limited, both in the family cluster (community) and in health services. There are several clusters of confirmed cases. The source of the origin of the infectious virus remains unclear and is under further research (WHO, 2015).

The case definition used in the Umrah health surveillance system adapts to the officer diagnostic capabilities of Port Health Office of Class 1 Surabaya and to existing equipment and health facilities. Until now, officers of Port Health Office of Class 1 Surabaya and equipment have not been able to identify symptoms using laboratories or Xrays because they do not have medical laboratory facilities and X-rays to support. The diagnosis made by officers of Port Health Office of Class 1 Surabaya is an initial diagnosis which states that the suspect is based on clinical symptoms and travel history. Laboratory tests and X-rays are performed at the referral hospital. In the preparation of the Umrah pilgrim health surveillance system, some data is required. One of them is the health condition of the Umrah pilgrims. So far, there has been no health data for Umrah pilgrims. But with the enactment of Law No. 8 of 2019 concerning the Organization of Hajj and Umrah, since 2019 Umrah pilgrims who were previously only required to have an ICV as proof of meningococcus meningitis vaccination are now also required to have a doctor's certificate as a condition for carrying out the Umrah (Indonesian Government, 2019). This can support the implementation of Umrah health surveillance. This is in accordance with Yezli, et al (2016) that there is still a need for meningitis meningococcus vaccination in hajj and umrah pilgrims. According to Gautret \& Steffen (2016) that congregational congenital diseases have risk factors for disease transmission.

ICV data must also be included in the Umrah health surveillance system. Yezli et al (2016) argue that surveillance at the entrance is required to 
prevent and control the spread of disease in the community, including preventing the entry of disease. The surveillance team checks the vaccination status of pilgrims who arrive at each entrance by examining vaccination evidence cards and reporting cases of pilgrims without vaccination or whose vaccination status cannot be verified and recommending appropriate actions for those cases. The surveillance team is also responsible for identifying and managing sick pilgrims, giving notifications and referring suspected cases of infectious disease.

Methods of data collection, data processing and data analysis in the surveillance system that are compiled are still using simple technology. According to Alotaibi et al (2017) argues that electronic surveillance systems become effective public health tools and timely data management by stakeholders who are in different locations. This is in line with the opinion of Nsoesie et al (2015) that outbreaks of infectious diseases at mass gatherings can affect the health system of the destination region and pose a threat to local and global health. Most destination countries have also used new technology to access disease risk to improve surveillance approaches (Shafi et al., 2016). A new approach to disease surveillance using the internet, mobile applications and wireless sensor networks. A new approach to surveillance of this disease can produce early detection. If the pilgrimage health surveillance system is implemented, it is necessary to compile a web/android based application, as stated by KBIH respondents, so that the process of data collection, processing, and analysis can be accelerated, simplified and reduced data redundancy.

The surveillance flow was compiled in accordance with the law of Indonesian ministry of health no. 45 of 2014 that the implementation of health surveillance is carried out through data collection, data processing, data analysis, and dissemination as an inseparable unit to produce objective, measurable information that can be compared across time, between regions, and between community groups as material for decision making (Ministry of Health RI, 2014). This is in accordance with Elachola et al (2016) and AlTawfiq \& Memish (2014) which state that good health surveillance management and risk planning and communication are needed to make the mass gathering (hajj/Umrah) surveillance effort successful and beneficial.

Systematic incidental reports compiled in the Umrah health surveillance system is in accordance with the Hajj Health Surveillance Guidelines that the report made at a minimum can answer the magnitude of the problem based on the results of descriptive epidemiological analysis (time, place, person), responding to the risk of possible transmission to health workers, pilgrims/other pilgrimage/flight crew and handling activities that have been carried out, as well as recommendations as a follow-up effort (Ministry of Health RI, 2016).

The report compiled by PHO Class I of Surabaya in the umrah health surveillance system can also be used for alertness and early detection of MERS-CoV in both provincial and district/city areas. Print media sources, for example, bulletins or other electronic media can also be used to be aware of rumors or news that develops related to MERS$\mathrm{CoV}$ on pilgrims/Umrah or other travelers from infected countries. Evaluation activities can be the basis for determining the strategy for planning the surveillance system for the following year. Evaluation of the implementation of the surveillance system needs to be prepared, whether the surveillance system is useful or in accordance with what is expected. The evaluation approach used in the Umrah health surveillance system is the attribute approach.

The Umrah health surveillance system has not been tested due to time constraints. Trials can be carried out after this writing. Umrah health surveillance is new and involves many parties outside the PHO Class I of Surabaya. When compared with Hajj health surveillance, there are three differences. First, Hajj health surveillance that has been organized are those who are capable and national in nature, while the health surveillance for Umrah pilgrims is new and nobody has done it.

The second difference is that Hajj health surveillance uses information technology so that it can combine data from the country and Saudi Arabia, from pre-Hajj to Hajj pilgrimage, while Umrah health surveillance still uses manual methods.

The third difference is that outbreaks observed in the Hajj health surveillance guidelines are food poisoning, traffic accidents and Meningococcus Meningitis. There has been no update on the guidelines for Hajj health surveillance, while in the Umrah health surveillance, the observation would be on meningococcal meningitis, Ebola, MERS$\mathrm{CoV}$ and risk factors.

Umrah health surveillance to be as beneficial as Hajj health surveillance requires regulatory support from the government in accordance with the opinion of Rustika, Puspasari, \& Kusnali (2018) that it needs regulation and supervision in the 
supervision of the Umrah pilgrimage. According to Nugraha, Martiana, \& Indriani (2018) the way to ensure the use of data analysis and interpretation is through evaluation.

\section{CONCLUSION}

Umrah health surveillance system is compiled based on the components of data collection, data processing, data analysis and interpretation, as well as dissemination. However, the Umrah health system has not been tested and has not used information technology (web-based applications/android).

\section{ACKNOWLEDGMENT}

The authors would like to express their gratitude to the following persons: 1) the Head of the Port Health Office Class I of Surabaya and his staff who were willing to facilitate the research; 2) the Dean of the Faculty of Public Health, Universitas Airlangga and all the supervisors who have provided prominent support during the research.

\section{REFERENCES}

Al-Tawfiq, J. A., \& Memish, Z. A. (2014). Mass gathering medicine: 2014 hajj and umra preparation as a leading example. International Journal of Infectious Diseases, 27, 26-31. https://doi.org/10.1016/j.ijid.2014.07.001

Almutairi, M. M., Alsalem, W. S., Hassanain, M., \& Hotez, P. J. (2018). Hajj, umrah, and the neglected tropical diseases. PLoS Neglected Tropical Diseases, 12(8), 1-9. https://doi.org/10.1371/journal.pntd.0006539

Alotaibi, B. M., Yezli, S., Saeed, A. A. A. Bin, Turkestani, A., Alawam, A. H., \& Bieh, K. L. (2017). Strengthening health security at the hajj mass gatherings: characteristics of the infectious diseases surveillance systems operational during the 2015 Hajj. Journal of Travel Medicine, 24(3), 1-6. https://doi.org/10.1093/jtm/taw087

Alqahtani, A. S., Wiley, K. E., Mushta, S. M., Yamazaki, K., BinDhim, N. F., Heywood, A. E., ... Rashid, H. (2016). Association between Australian hajj pilgrims' awareness of MERS$\mathrm{CoV}$, and their compliance with preventive measures and exposure to camels. Journal of Travel Medicine, 23(5), 1-5. https://doi.org/10.1093/jtm/taw046
Elachola, H., Gozzer, E., Zhuo, J., Sow, S., Kattan, R. F., Mimesh, S. A., ... Memish, Z. A. (2016). Mass gatherings: a one-stop opportunity to complement global disease surveillance. Journal of Health Specialties, 4(3), 178-185. https://doi.org/10.4103/24686360.186487

Gardner, L. M., Chughtai, A. A., \& Maclntyre, C. R. (2016). Risk of global spread of middle east respiratory syndrome coronavirus (MERS-CoV) via the air transport network. Journal of Travel Medicine, 23(6), 1-8. https://doi.org/10.1093/jtm/taw063

Gautret, P., \& Steffen, R. (2016). Communicable diseases as health risks at mass gatherings other than hajj: what is the evidence? International Journal of Infectious Diseases, 47, 46-52. https://doi.org/10.1016/j.ijid.2016.03.007

Indonesian Government. (2019). Law number 8 of 2019 concerning the organization of the hajj and umrah. Jakarta: Indonesian Government.

Memish, Z. A., Zumla, A., Alhakeem, R. F., Assiri, A., Turkestani, A., Al Harby, K. D., ... AlTawfiq, J. A. (2014). Hajj: infectious disease surveillance and control. The Lancet, 383(9934), 1-10. https://doi.org/10.1016/S01406736(14)60381-0

Ministry of Health RI. (2014). Regulation of the Minister of Health of the Republic of Indonesia number 45 of 2014 concerning the implementation of health surveillance. Jakarta: Ministry of Health RI.

Ministry of Health RI. (2016). Regulation of the Minister of Health of the Republic of Indonesia number 62 of 2016 concerning the implementation of health on hajj. Jakarta: Ministry of Health RI.

Nsoesie, E. O., Kluberg, S. A., Mekaru, S. R., Majumder, M. S., Khan, K., Hay, S. I., \& Brownstein, J. S. (2015). New digital technologies for the surveillance of infectious diseases at mass gathering events. Clinical Microbiology and Infection, 21(2), 134-140. https://doi.org/10.1016/j.cmi.2014.12.017

Nugraha, A., Martiana, T., \& Indriani, D. (2018). Surveillance system development based on NCD inegrated post (Posbindu PTM) as an effort of occupational health services. Indian Journal of Public Heakth Research \& Development, 9(5), 153-157. https://doi.org/10.5958/09765506.2018.00492.8

Rustika, Puspasari, H. W., \& Kusnali, A. (2018). 
Policy analysis of the Umrah pilgrimage meningitis vaccination service in Indonesia. Buletin Penelitian Sistem Kesehatan, 21(1), 60-70. https://doi.org/10.22435/hsr.v21i1.96

Shafi, S., Dar, O., Khan, M., Khan, M., Azhar, E. I., McCloskey, B., ... Petersen, E. (2016). The annual hajj pilgrimage - minimizing the risk of ill health in pilgrims from Europe and opportunity for driving the best prevention and health promotion guidelines. International Journal of Infectious Diseases, 47 , 79-82. https://doi.org/10.1016/j.ijid.2016.06.013

WHO. (2015). Fact sheet on middle east respiratory syndrome coronavirus (WHO June 2015). World Health Organization. Geneva.

Wignjadiputro, I., Susilarini, N. K., Praptiningsih, C. Y., Sariwati, E., Setiawaty, V., \& Samaan, G. (2018). Surveillance for severe acute respiratory infection as one approach to enhance global health security in Indonesia. Health Science Journal of Indonesia, 9(1), 813. https://doi.org/10.22435/hsji.v9i1.473

Yezli, S., Assiri, A. M., Alhakeem, R. F., Turkistani, A. M., \& Alotaibi, B. (2016). Meningococcal disease during the Hajj and Umrah mass gatherings. International Journal of Infectious Diseases, 47, 60-64. https://doi.org/10.1016/j.ijid.2016.04.007

Yezli, S., Saeed, A. A. Bin, Assiri, A. M., Alhakeem, R. F., Yunus, M. A., Turkistani, A. M., ... Alotaibi, B. M. (2016). Prevention of meningococcal disease during the hajj and umrah mass gatherings: past and current measures and future prospects. International Journal of Infectious Diseases, 47, 71-78. https://doi.org/10.1016/j.ijid.2015.12.010

Zumla, A., Saeed, A. Bin, Alotaibi, B., Yezli, S., Dar, O., Bieh, K., ... Azhar, E. I. (2016). Tuberculosis and mass gatheringsopportunities for defining burden, transmission risk, and the optimal surveillance, prevention, and control measures at the annual hajj pilgrimage. International Journal of Infectious Diseases, 47, 86-91. https://doi.org/10.1016/j.ijid.2016.02.003 